\title{
PENGARUH DIMENSI BAURAN PEMASARAN TERHADAP MINAT NASABAH MENGGUNAKAN LAYANAN E-BANKING
}

\author{
Adiyatma Surya Firdaus ${ }^{1) *}$, Herman Sjahruddin'), Zulfikry Sukarno ${ }^{2)}$ Andi Tenriola ${ }^{2)}$ \\ ${ }^{1)}$ Manajemen Perbankan,Sekolah Tinggi Ilmu Ekonomi Makassar Bongaya, Makassar,Sulawesi Selatan \\ 2) Sekolah Tinggi Ilmu Ekonomi Makassar Bongaya, Makassar,Sulawesi Selatan \\ *Penulis Korespondensi: adiyatma98surya@gmail.com
}

\begin{abstract}
Penelitian ini bertujuan untuk mengetahui apakah Dimensi Bauran Pemasaran berpengaruh terhadap Minat Nasabah Menggunakan Layanan E-Banking Pada PT.Bank BNI Syariah Kantor Cabang Makassar.. Pengumpulan data menggunakan data primer yang diperoleh dari hasil kuesioner sebesar 40 respoenden, dengan menggunakan teknik sampling jumlah indikator dikali 5-10. Hasil penelitian tersebut telah diuji asumsi klasik berupa asumsi normalitas, autokolerasi, multikolineritas, heteroskedastisitas dan linearitas. Metode analisis data menggunakan teknik regresi linear berganda. Hasil penelitian menunjukkan bahwa hipotesis yang diajukan diterima karena menunjukkan hasil uji hipotesis yang positif dan signifikan. Ini berarti bahwa variabel rasio aktivitas berpengaruh positif dan signifikan terhadap rentabilitas, variabel ukuran perusahaan berpengaruh positif dan signifikan terhadap profitabilitas, dan variabel rasio aktivitas dominan berpengaruh terhadap rentabilitas.
\end{abstract}

Keywords: Bauran Pemasaran, Minat Nasabah, E-Banking 


\section{PENDAHULUAN}

Perbankan dalam memberikan pelayanan prima kepada nasabah, saat ini penerapannya dilakukan salah satunya dengan E-banking, yang merupakan bentuk layanan tanpa batas waktu dan ruang untuk mempermudah transaksi serta mengurangi beban kerja perbankan untuk meningkatkan mutu layanan berbasis teknologi dan informasi. Dalam upaya memenuhi perkembangan teknologi informasi yang serba cepat maka layanan Perbankan dari tahun ke tahun semakin bersaing antara satu bank dengan bank lainnya.

Setiap perbankan yang ada di Indonesia selalu ingim memperbaiki kualitas layanannya melalui minat nasabah untuk mengambil keputusan dalam penggunaan e-banking. Adapun manfaat e- banking BNI yaitu dapat diakses melaui PC/laptop dan handphone/smartphone, dapat melakukan transfer dana dengan limit transaksi hingga 1 milyard 1 hari, multi transfer, trasnfer terjadwal dan berulang, dapat melakukan pembukaan rekening Taplus, Deposito dan Tappenas, memiliki otoritasi transaksi finasnsial e-secure atau BNI m-secure, menggunakan otorisasi saat melakukan login ke BNI internet banking yaitu USER ID, Password, ,yang dapat membuat perencanaan keuangan, memantau grafik cash flow, melakukan transfer rekening BNIantar mata uang yang sama maupun dari USD/SGD ke IDR, notifikasi transaksi dapat berupa email dan SMS

Akhir- akhir ini banyak sekali perubahan pada teknologi informasi, demikian juga dibidang telekomunikasi kebanyakan disebabkan adanya desakan kompetisi di dunia perbankan. Banyaknya pengguna internet di Indonesia tidak dapat dipungkiri juga untuk mendorong dunia bisnis untuk lebih maju dan berkembang. Internet menjadi media untuk melakukan transaksi penjualan dan pembelian. Selain itu internet menjadi media untuk mencari informasi dan bertukar informasi. Teknologi informasi juga mendorong dunia perbankan untuk ikut andil dalam memanfaatkan internet. Kesempatan ini digunakan perbankan untuk melangkah maju dengan memberikan pelayanan yang lebih baik kepada para nasabahnya yaitu tidak hanya menawarkan kecepatan dalam melakukan transaksi tetapi juga kemudahan serta kenyamanan bagi nasabah untuk melakukan transaksi keuangan maupun non keuangan secara online tanpa mengharuskan nasabahnya untuk datang dan mengantri di bank atau ATM.

Menurut hasil survei yang dilakukan Otoritas Jasa Keuangan salah satu industri yang sangat maju dengan perkembangan teknologi adalah perbankan. Dewasa ini masyarakat cenderung beralih menjadi cash less society tanpa harus membawa uang tunai dalam jumlah banyak dalam aktivitasnya dengan memanfaatkan layanan perbankan yang didukung oleh teknologi yang efisien dan efektif (Otoritas Jasa Keuangan, 2015). Peningkatan kualitas teknologi yang efisien dan efektif dengan dukungan pemasaran jasa perbankan dengan menggunakan bauran pemasaran yang meliputi Product, Place, Price, Promotion,dan Proses yang berorientasi pada peningkatan jumlah nasabah, maka kinerja bank dapat ditingkatkan, diantara lima bauran pemasaran tersebut terdapat tiga dimensi bauran terpenting dalam meningkatkan minat nasabah yaitu , Product,Promotion, dan Proses.(Corry, 2019).

Minat adalah pengaruh eksternal, kesadaran akan kebutuhan,pengenalan produk dan evaluasi alternatif adalah hal yang menimbulkan minat beli konsumen. Pengaruh ekstenal ini terdiri dari usaha pemasaran dan faktor sosial budaya. (Schifman dan Kanuk, 2010). Minat nasabah berdasarkan teorinya merujuk pada confirmation theory yang dikemukakan oleh (Oliver;1986, Ramli dan Sjahruddin, 2015), yang menjelaskan bahwa nasabah tertarik / berminat untuk menjadi nasabah perbankan disebabkan karena adanya harapan mereka

Menurut hasil Survei Nasional Literasi dan Inklusi Keuangan (SNLIK) ketiga yang dilakukan Otoritas Jasa Keuangan (OJK) pada tahun 2019 menjelakan bahwa salah satu industri yang sangat maju dengan perkembangan teknologi adalah perbankan. Dewasa ini pada saat dilakukannya prapembelian, sehingga dengan demikian melakukan penilaian atau evaluasi terhadap 
jasa dan produk bank yang akan digunakannya, apabila sesuai dengan harapannya maka terjadi konfirmasi atau keinginan untuk menjadi nasabah sebaliknya apabila tidak sesuai dengan harapan mereka, maka terjadi diss-confirmasi atau keengganan menjadi nasabah.

Pemilihan Bank BNI Syariah Kantor Cabang Makassar, Berdasakan Hasil pengamatan yang bersumber dari dokumen Bank BNI Syariah Syariah Kantor Cabang Makassar, yang datanya ditunjukkan pada tabel berikut :

Tabel 1. Nasabah BNI Syariah Syariah Kantor Cabang Makassar

\begin{tabular}{|c|c|c|}
\hline TAHUN & $\begin{array}{c}\text { NASABAH } \\
\text { PENGGUNA }\end{array}$ & PERUBAHAN \\
\hline 2017 & 3.679 & - \\
\hline 2018 & 5.630 & 1.951 \\
\hline 2019 & 8.211 & 2.581 \\
\hline
\end{tabular}

Hasil pengamatan yang bersumber dari dokumen Bank BNI Syariah Syariah Kantor Cabang Makassar dapat menunjukkan pengguna layanan E-Banking mengalami kenaikan yang sangat signifikan. Kenaikan jumlah nasabah disebabkan karena tingginya minat nasabah untuk memperoleh layanan yang cepat dan mudah. Jumlah nasabah Bank BNI tahun 20173.679 nasabah , dan di tahun 2018 mengalami perubahan menjadi 5.630, dan di tahun 2019 mengalami kenaikan 8.211 nasabah. Sehingga menjadi salah satu reasoning riset, selain itu studi ini menganalisis apakah kenaikan nasbah yang diperoleh perbankan syariah diakibatkan karena efektivitas bauran pemasaran yang digunakan selama ini.

\section{TINJAUAN PUSTAKA}

\section{A. Tinjauan Teoritis}

\section{Konsep Bank dan Perbankan Syariah}

\section{a. Pengertian dan fungsi Bank}

Bank adalah badan usaha yang menghimpun dana dari masyarakat dalam bentuk simpanan dan menyalurkannya pada masyarakat dalam bentuk kedit lainnya dalam rangka meningkatkan taraf hidup rakyat banyak. Menurut Kasmir (2012), secara sederhana bank dapat diartikan sebagai lembaga keuangan yang kegiatan usahanya adalah menghimpun dana dari masyarakat dan menyalurkan kembali dana tersebut ke masyarakat serta memberikan jasa-jasa bank lainnya.

\section{b. Pengertian dan fungsi perbankan syariah}

Bank Syariah adalah Bank yang menjalankan kegiatan usahanya berdasarkan Prinsip Syariah dan menurut jenisnya terdiri atas Bank Umum Syariah dan Bank Pembiayaan Rakyat Syariah. Bank Umum Syariah adalah Bank Syariah yang dalam kegiatannya memberikan jasa dalam lalu lintas pembayaran. Fungsi bank syariah sama seperti halnya bank umum, bank syariah memiliki fungsi utama sebagai penghimpun dana dari masyarakat.

Bedanya, jika pada bank konvensional si penabung mendapatkan balas jasa berupa bunga, di bank syariah penabung akan mendapatkan balas jasa berupa bagi hasil.

Menurut Ramli (2017) bahwa kegiatan sebuah bank adalah untuk mencapai tujuan yang telah dibuat sebelumnya. Tujuan perbankan sendiri adalah untuk memaksimalkan atau mengoptimalkan nilai kekayaan yang dimiliki oleh para pemegang saham yang mempercayakan dananya ke bank. Nilai kekayaan yang dimiliki oleh pemegang saham tersebut berasal dari harga saham di pasar modal. Maka dari itu, hal yang sangat penting dalam manajemen perbankan adalah memahami variabel yang dibutuhkan dalam pasar modal, teori keuangan, harga saham, dan indikator pasar modal.

\section{Konsep E-banking a. Pengertian E-Banking}

Electronic Banking, atau E-Banking bisa diartikan sebagai aktifitas perbankan di internet. Layanan ini memungkinkan nasabah sebuah bank dapat melakukan hampir semua jenis transaksi perbankan melalui sarana internet, khususnya via web. Quinn dan Baily menyatakan perusahaan memiliki beberapa keuntungan dengan adanya investasi dalam teknologi informasi. (Wulan Pinontoan, 2012).

\section{b. Bentuk - bentuk layanan E-Banking}

Jenis-Jenis E-Banking Perkembangan pesat teknologi informasi (IT) dan globalisasi mendukung bank untuk meningkatkan pelayanan kepada nasabah secara aman, 
nyaman, dan efektif, diantaranya melalui media elektronik atau dikenal dengan Elektronik Banking (ebanking). E-banking merupakan layanan yang memungkinkan nasabah bank untuk memperoleh informasi, melakukan komunikasi, dan melakukan transaksi perbankan melalui media elektronik seperti Automatic Teller Machine (ATM), Elektronic Data Capture (EDC)/ Poin Of Sales (POS), internet banking, SMS banking, mobile banking, ecommerce, phone banking, dan video banking (Jaringan:Tim OJK, 2015).

\section{Konsep Bauran Pemasaran a. Pengertian Pemasaran}

Menurut Kotler dan Amstrong (2012:29), "Marketing as the process by which companies create value for customers and build strong customer relationships in order to capture value from customers in return", artinya menyatakan bahwa pemasaran sebagai proses dimana perusahaan menciptakan nilai bagi pelanggan dan membangun hubungan pelanggan yang kuat untuk menangkap nilai dari pelanggan sebagai imbalan.

Menurut Melydrum dalam Sudaryono (2016:41), pemasaran adalah proses bisnis yang berusaha menyelaraskan antara sumber daya manusia, finansial dan fisik organisasi dengan kebutuhan dan keinginan para pelanggan dalam konteks strategi kompetitif. Jadi dapat disimpulkan, pemasaran adalah suatu kegiatan perekonomian yang dilakukan untuk memenuhi kebutuhan dan keinginan konsumen dengan produk yang telah ditawarkan oleh perusahaan. Jadi dapat disimpulkan, pemasaran adalah suatu kegiatan perekonomian yang dilakukan untuk memenuhi kebutuhan dan keinginan konsumen dengan produk yang telah ditawarkan oleh perusahaan.

\section{b. Pengertian Bauran Pemasaran}

Kotler (2012:101) menyatakan bahwa bauran pemasaran merupakan seperangkat alat pemasaran yang digunakan suatu perusahaan untuk terus menerus mencapai tujuan pemasarannya di pasar sasaran. Berdasarkan definisi diatas dapat disimpulkan bahwa bauran pemasaran merupakan alat yang baik yang berada dalam suatu perusahaan, agar dapat mempengaruhi respon sasaran. Dalam bauran pemasaran terdapat seperangkat alat yang dikenaal dalam istilah 4P, yaitu product (produk), price (harga), place (tempat), dan promotion (promosi), sedangkan dalam pemasaran jasa memiliki beberapa alat pemasaran tambahan seperti people (orang), physical evidence (fasilitas fisik), dan process (proses), sehingga dikenal dengan istilah 7P

\section{Konsep Minat Nasabah}

\section{a. Teori Confirmation}

Nasabah menggunakan jasa dan produk bank menyusaikan dengan harapan mereka pada saat dilakukan pra-pembelian sehingga dengan demikian nasabah dilakukan penilaian atas jasa dan produk bank dikerjakan dari barang maupun jasa yang telah digunakan oleh nasabah. (Oliver;1986, Ramli dan Sjahruddin, 2015)

\section{b. Pengertian Minat Nasabah}

Minat adalah pengaruh

eksternal,kesadaran akan

kebutuhan,pengenalan produk dan evaluasi alternatif adalah hal yang menimbulkan minat beli konsumen. (Schifman dan Kanuk, 2010).

\section{KERANGKA KONSEPTUAL}

Bauran pemasaran yang dapat digunakan adalah dimensi produk, promosi, dan proses. (Philip Kotler \& Kevin Lane Keller, 2010) Dalam penelitian ini, produk yang dimaksud adalah sesuatu yang dapat ditawarkan kepada seseorang untuk memuaskan suatu kebutuhan dan keinginan transaksi atau cek saldo yang dapat dilakukan melalui m-banking.

Adapun promosi yang dimaksud adalah promosi m-banking dimana PT. Bank BNI Syari'ah biasanya mempromosikan mbanking langsung kepada nasabah yang akan membuka rekening atau pada saat bertanya pada customer service mengenai produk maupun layanan yang ada di PT. Bank BNI Syari'ah.

Proses adalah semua prosedur, mekanisme rutin untuk mendapatkan pelayanan m-banking bagi nasabah. Semakin mudah proses mendapatkan suatu produk atau jasa, maka akan semakin banyak nasabah yang berminat menggunakan produk tersebut. 


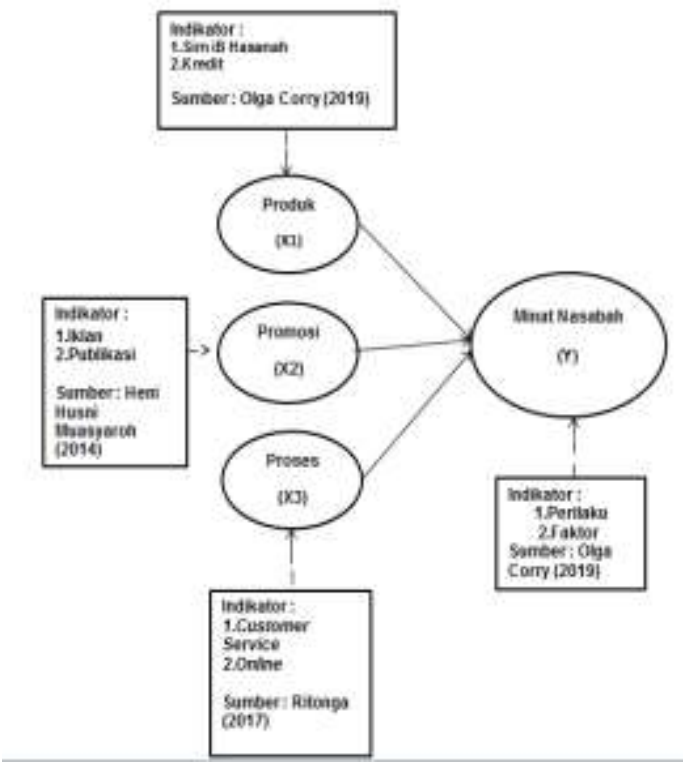

Gambar 1 Kerangka Penelitian

Semakin tinggi kesusaian nasabah dengan produk yang ditawarkan perbankan, maka semakin tinggi minat nasabah menggunakan layanan E-Banking. Studi yang dilakukan Olga Corry (2019), memberikan bukti bahwa bauran pemasaran pada dimensi produk berpenaruh terhadap minat nasabah minat nasabah menggunakan E-Banking.

Semakin baik promosi yang dilakukan bank kepada nasabah, maka semakin tinggi minat nasabah menggunakan layanan EBanking. Pernyataan tersebut mengkonfirmasi temuan Muasyaroh (2014), bahwa promosi berpengaruh terhadap minat nasabah minat nasabah menggunakan E-Banking PT. Bank BNI Syariah Yogyakarta.

Semakin baik proses yang dilakukan bank kepada nasabah, maka semakin tinggi minat nasabah menggunakan layanan EBanking. Temuan Ritonga (2017), memberikan bukti bahwa pengaruh bauran pemasaran pada dimensi proses berpengaruh terhadap minat nasabah minat nasabah menggunakan EBanking PT. Bank Syariah Mandiri Kantor Cabang Padangsidimpuan.

\section{METODE PENELITIAN}

Jenis data yang digunakan adalah data kuantitatif yang diperoleh dari hasil penyebaran kuesioner kepada para responden dalam bentuk tertulis yang diberi skor dalam bentuk angka-angka dan digunakan untuk menganalisis hasil penelitian. Kuesioner di distribusikan pada 40 (Sugiyono, 2013:199).

Analisis regresi linear berganda digunakan untuk menganalisis pengaruh variabel independen terhadap variabel dependen. Formulasi dari model yang akan digunakan adalah:

$\begin{array}{lll}\mathrm{Y}=\alpha+\beta 1 \mathrm{X} 1+\beta 2 \mathrm{X} 2+\beta 3 \mathrm{X} 3+\mathrm{e} \\ \text { Dimana : } & \\ \mathrm{Y}= & \text { Minat Nasabah } \\ \alpha \quad= & \text { Konstanta } \\ \mathrm{X}_{1}= & \text { Produk } \\ \mathrm{X}_{2}= & \text { Promosi } \\ \mathrm{X}_{3}= & \text { Proses } \\ \beta 1, \beta 2= & \text { Koefisien regresi } \\ \mathrm{e} & = & \text { Error Standard }\end{array}$

\section{HASIL DAN PEMBAHASAN}

\section{Karakteristik Responden}

Tabel 2. Jenis Kelamin Responden

\begin{tabular}{|c|c|c|}
\hline Jenis Kelamin & Frekuensi & $\begin{array}{c}\text { Persentase } \\
(\%)\end{array}$ \\
\hline Laki-laki & 19 & 47,5 \\
\hline Perempuan & 21 & 52,5 \\
\hline Jumlah & 40 & 100 \\
\hline
\end{tabular}

Tabel tersebut menunjukkan bahwa mayoritas responden adalah berjenis kelamin laki-laki yaitu sebanyak 19 nasabah atau $47,5 \%$ dan sisanya 21 nasabah atau $52,5 \%$ adalah berjenis kelamin perempuan. Hal ini disebabkan oleh nasabah yang mengisi kuesioner lebih banyak perempuan dari pada laki-laki. 1

Tabel 3. Usia Responden

\begin{tabular}{|c|c|c|}
\hline Usia & Frekuensi & Persentase (\%) \\
\hline $20-25$ & & \\
Tahun & 30 & 75 \\
\hline $26-30$ & & \\
Tahun & 10 & 25 \\
\hline Jumlah & 40 & 100 \\
\hline
\end{tabular}

Tabel 3 menunjukkan bahwa kelompok usia 20-25 tahun yang menjadi responden sebanyak 30 nasabah $(75 \%)$ dan kelompok usia 26-30 tahun yang menjadi responden sebanyak 10 nasabah (25\%). Berdasarkan penjelasan di atas dapat disimpulkan bahwa yang menjadi sampel 
untuk dijadikan responden paling banyak adalah nasabah yang umurnya 20-25 tahun. Hal ini disebabkan karena kelompok umur tersebut merupakan kategori usia dominan.

\section{Uji Instrumen}

Tabel 4. Validitas Dimensi Produk

\begin{tabular}{|c|c|c|c|}
\hline Indikator & $\mathrm{r}_{\text {hitung }}$ & $\mathrm{r}_{\text {tabel }}$ & Keterangan \\
\hline $\mathrm{X}_{11}$ & 0,982 & 0,304 & Valid \\
\hline $\mathrm{X}_{12}$ & 0,974 & 0,304 & Valid \\
\hline
\end{tabular}

Tabel 4 menunjukkan seluruh item indikator mengenai dimensi produk menunjukkan bahwa $\mathrm{r}_{\text {-hiung }}>\mathrm{r}_{\text {-tabel }}$ sebesar 0.304 sehingga indikator pada variabel produk dapat dikatakan valid.

Tabel 5. Validitas Dimensi Promosi

\begin{tabular}{|c|c|c|c|}
\hline Indikator & $\mathrm{r}_{\text {hitung }}$ & $\mathrm{r}_{\text {tabel }}$ & Keterangan \\
\hline $\mathrm{X}_{21}$ & 0,947 & 0.304 & Valid \\
\hline $\mathrm{X}_{22}$ & 0,950 & 0,304 & Valid \\
\hline
\end{tabular}

Tabel 5 menunjukkan jika seluruh item indikator pada dimensi promosi memperlihatkan jika nilai $\mathrm{r}_{\text {-hiung }}>\mathrm{r} \mathrm{r}_{\text {tabel }}$ sebesar 0.304 sehingga indikator pada dimensi promosi dapat dikatakan valid.

Tabel 6. Validitas Dimensi Proses

\begin{tabular}{|c|c|c|c|}
\hline Indikator & $\mathrm{r}_{\text {hitung }}$ & $\mathrm{r}_{\text {tabel }}$ & Keterangan \\
\hline $\mathrm{X}_{31}$ & 0,976 & 0,304 & Valid \\
\hline $\mathrm{X}_{32}$ & 0,935 & 0,304 & Valid \\
\hline
\end{tabular}

Tabel 6 memperlihatkan jika seluruh item indikator mengenai variabel proses, nilai $\mathrm{r}^{-}$hiung $>\mathrm{r}_{\text {-tabel }}$ sehingga indikator pada dimensi proses dapat dikatakan valid.

Tabel 7. Validitas Minat Nasabah

\begin{tabular}{|c|c|c|c|}
\hline Indikator & $\mathrm{r}_{\text {hitung }}$ & $\mathrm{r}_{\text {tabel }}$ & Keterangan \\
\hline $\mathrm{Y}_{11}$ & 0,905 & 0,304 & Valid \\
\hline $\mathrm{Y}_{12}$ & 0,864 & 0,304 & Valid \\
\hline
\end{tabular}

Tabel 7 membuktikan jika seluruh item indikator mengenai variabel minat nasabah dapat dikatakan valid.

Tabel 8. Uji Reabilitas

\begin{tabular}{|c|c|c|}
\hline Variabel & $\begin{array}{c}\text { Cronbach's } \\
\text { Alpha }\end{array}$ & $\begin{array}{c}\text { Keterangan } \\
>0.60\end{array}$ \\
\hline Produk & 0,947 & Terpenuhi \\
\hline
\end{tabular}

\begin{tabular}{|c|c|c|}
\hline$\left(\mathrm{X}_{1}\right)$ & & \\
\hline $\begin{array}{c}\text { Promosi } \\
\left(\mathrm{X}_{2}\right)\end{array}$ & 0,887 & Terpenuhi \\
\hline $\begin{array}{c}\text { Proses } \\
\left(\mathrm{X}_{3}\right)\end{array}$ & 0,856 & Terpenuhi \\
\hline $\begin{array}{c}\text { Minat } \\
\text { Nasabah } \\
(\mathrm{Y})\end{array}$ & 0,717 & Terpenuhi \\
\hline
\end{tabular}

Hasil uji reliabilitas pada tabel 8 menunjukkan bahwa Cronbach'sAlpha seluruh variabel ebih besar dari 0,60 , sehingga semua kuesioner variabel dinyatakan reliabel sebagai alat ukur.

\section{Uji Statistik Deskriptif}

Tabel 9. Statistik Deskriptif

\begin{tabular}{|l|r|r|r|}
\hline & Mean & $\begin{array}{c}\text { Std. } \\
\text { Deviation }\end{array}$ & \multicolumn{1}{l|}{ N } \\
\hline Minat & 31.462 & .96841 & 40 \\
\hline Produk & 30.495 & 113.005 & 40 \\
\hline Promosi & 30.250 & 106.388 & 40 \\
\hline Proses & 30.335 & 109.015 & 40 \\
\hline
\end{tabular}

Produk dalam penelitian ini menujukan nilai mean yaitu 3.049 dan nilai standar deviasi yaitu 1.130 dari hasil tesebut memberikan penjelasan nilai mean > dari nilai standar deviasi sehingga dapat dikatakan bahwa data pada dimensi produk dalam penelitian dapat digunakan sebagai representasi data.

Promosi dalam penelitian ini menujukan nilai mean yaitu 3.025 dan nilai standar deviasi yaitu 1.063, dari hasil tesebut memberikan penjelasan nilai mean > dari nilai standar deviasi sehingga dapat dikatakan bahwa data pada dimensi promosi dapat digunakan sebagai representasi data.

Proses pada penelitian ini menujukan nilai mean yaitu 3.033 dan nilai standar deviasi yaitu 1.090 dari hasil tesebut memberikan penjelasan nilai mean > dari nilai standar deviasi sehingga dapat dikatakan bahwa data pada dimensi proses dapat digunakan sebagai representasi data

Minat Nasabah penelitian ini menujukan nilai mean yaitu 3.146 dan nilai standar deviasi yaitu 0,968 dari hasil tesebut memberikan penjelasan nilai mean > dari nilai standar deviasi sehingga dapat dikatakan bahwa data pada variabel minat nasabah penelitian ini baik digunakan sebagai representasi data 
variabel independen bebas dari masalah heteroskedasitas

\section{Uji Asumsi Klasik}

Tabel 10. Normalitas Data

\begin{tabular}{|c|c|}
\hline & $\begin{array}{c}\text { Unstandardized } \\
\text { Residual }\end{array}$ \\
\hline $\begin{array}{c}\text { Asymp. Sig. (2- } \\
\text { tailed) }\end{array}$ & $.200^{\mathrm{c}, \mathrm{d}}$ \\
\hline
\end{tabular}

Tabel 10. menunjukkan bahwa Kolmogorov-Smirnov dengan nilai Asymp.sig (2-tailed) sebesar 0,200>0,05 sehingga dapat dikatakan bahwa data tersebut berdistribusi normal. Sehingga dapat dikatakan bahwa data tersebut berdistribusi normal.

Tabel 11. Multikolinieritas Data

\begin{tabular}{|c|c|c|}
\hline \multirow{2}{*}{ Model } & \multicolumn{2}{|c|}{ Collinearity Statistics } \\
\cline { 2 - 3 } & Tol. & VIF \\
\hline Produk & .442 & 2.264 \\
\hline Promosi & .231 & 4.323 \\
\hline Proses & .254 & 3.933 \\
\hline
\end{tabular}

Tabel 11 memberikan bukti jika nilai Tolerance variabel Produk (X1) yakni sebesar 0,442 lebih besar dari 0,10 . Dan nilai VIF sebesar $2.26<$ dari 10. Nilai Tolerance variabel Promosi $\left(\mathrm{X}_{2}\right)$ yakni sebesar 0,231 lebih besar dari 0,10. Dan nilai VIF sebesar $4.32<$ dari 10. Nilai Tolerance variabel Proses $\left(\mathrm{X}_{3}\right)$ yakni sebesar 0,254 lebih besar dari 0,10. Dan nilai VIF sebesar 3.933 dari 10. Sehingga dapat dikatakan bahwa tidak terjadi korelasi pada variabel produk (tidak terjadi Multikolinearitas)

\section{Uji Heteroskedastisitas}

Tabel 12.Uji Heteroskedastisitas

\begin{tabular}{|c|c|}
\hline Model & P-value $>0.05$ \\
\hline Produk & .655 \\
\hline Promosi & .638 \\
\hline Proses & .650 \\
\hline
\end{tabular}

Tabel 12 menunjukkan bahwa variabel independen yaitu Produk memiliki nilai sig $0,65>0,05$, variabel Promosi memiliki nilai sig 0,638>0,05, dan variabel Proses memiliki nilai sig 0,650 . Dengan demikian, semua
Uji Autokorelasi

Tabel 13. Uji Autokorelasi

\begin{tabular}{|c|c|c|c|}
\hline \multicolumn{4}{|c|}{ Change Statistics } \\
\hline df1 & df2 & $\begin{array}{c}\text { Sig.F } \\
\text { Change }\end{array}$ & $\begin{array}{c}\text { Durbin } \\
\text { Watson }\end{array}$ \\
\hline 3 & 36 & .000 & 1.439 \\
\hline
\end{tabular}

Tabel 13 menunjukkan jika nilai DW (Durbin Watson) 1.439. Selanjutnya nilai ini akan kita bandingkan dengan nilai tabel DW dengan signifikansi $5 \%$, diketahui jumlah data $\mathrm{N}=40$ dan jumlah variabel independen $\mathrm{K}=4$ maka diperoleh nilai du (batas atas) sebesar 1,720. Nilai DW ini lebih besar dari batas atas (du) yakin 1,720 dan nilai DW sebesar 1,439 tersebut lebih dari $(4-\mathrm{du}) 4-1,720=2,28$. Sehingga dapat disimpulkan bahwa tidak terdapat autokorelasi positif.

Analisis Regresi Linear Berganda Tabel 14. Analisis Regresi Linear Berganda

\begin{tabular}{|l|c|}
\hline \multicolumn{1}{|c|}{ Model } & $\begin{array}{c}\text { Unstandardized } \\
\text { Coefficients }\end{array}$ \\
\hline (Constant) & 1.285 \\
\hline Standard error & 0.388 \\
\hline Produk & .431 \\
\hline Promosi & -.039 \\
\hline Proses & .312 \\
\hline
\end{tabular}

Berdasarkan tabel 5.13 dapat dirumuskan suatu persamaan regresi untuk mengetahui pengaruh Produk,Promosi,dan Proses terhadap Minat Nasabah adalah sebagi berikut:

$$
\begin{aligned}
& Y=\alpha+\beta 1 X 1-\beta 2 X 2+\beta 3 X 3+e \\
& Y=1,285+0,431-0,039+0,312+0.388
\end{aligned}
$$

Model regresi tersebut di atas dapat diartikan bahwa nilai koefisien berarti secara statistik jika semua variabel bebas bernilai 0 , maka nilai variabel terikat bernilai 1,285 . Nilai regresi dari produk 0,431 dan proses 0,312 memiliki nilai positif sedangkan pada variabel promosi memiliki nilai negatif sebesar $-0,039$. Maka dapat digambarkan jika ada kenaikan nilai sebesar 1 pada variabel produk dan proses maka setiap variabel akan meningkat $1 \%$, begitupun sebaliknya jika ada penurun sebesar 1 maka setiap variabel akan menurun $1 \%$. 


\section{Hasil Pengujian Hipotesis}

Tabel 15. Uji Anova

\begin{tabular}{|c|c|c|}
\hline Model & F-test & p-value \\
\hline Regression & 8.998 & $.000^{\mathrm{b}}$ \\
\hline
\end{tabular}

Tabel 15 menunjukkan jika nilai F-hit sebesar 8,988 dan nilai F-tab sebesar 2,63. Oleh karena itu F-hit 8,988 > F-tab 2,63 maka dengan derajat kekeliruan $5 \%(\alpha=0,05) \mathrm{Ha}_{\mathrm{a}}$ diterima Ho ditolak (hipotesis diterima) dan dengan nilai signifikan $0.000<0.05$. Artinya dengan tingkat kepercayaan $95 \%$ dapat dikatakan bahwa model yang digunakan terpenuhi berdasarkan goodness of fit.

Tabel 16. Uji Hipotesis

\begin{tabular}{|c|c|c|}
\hline Model & $\mathrm{t}$-stat & $\mathrm{p}$-value \\
\hline Produk & 2.276 & .029 \\
\hline Promosi & -.148 & .883 \\
\hline Proses & 1.248 & .220 \\
\hline
\end{tabular}

Berdasarkan tabel 16 dapat diketahui hasil pengolahan data yang terdapat pada tabel tersebut diperoleh t-hitung untuk masingmasing variabel independen yaitu produk sebesar 2,276, promosi -0,148, dan proses sebesar 1,248.

Dengan demikian pengujian hipotesis untuk mengetahui apakah variabel independen secara parsial berpengaruh signifikan terhadap variabel dependen dalam penelitian ini dapat dijelaskan sebagai berikut:

\section{Pengaruh produk terhadap Minat nasabah.}

Hasil analisis memberikan bukti bahwa kausalitas antara produk (X1) dengan minat nasabah $(\mathrm{Y})$ diperoleh data yakni $\mathrm{t}$ hitung 2,276 Lebih besar dari t-tabel 2,028, maka pada tingkat kekeliruan 5\% Ho diterima dan $\mathrm{Ha}$ diterima (hipotesis ditolak) dan dengan nilai signifikan $0,02<0,05$ artinya signifikan. Maka dapat dikatakan bahwa produk (X1) secara parsial berpengaruh positif dan signifikan terhadap minat nasabah $(\mathrm{Y})$.

Pengaruh promosi terhadap minat nasabah.

Hasil analisis memberikan bukti bahwa kausalitas antara promosi $\left(\mathrm{X}_{2}\right)$ dengan minat nasabah (Y) diperoleh nilai t-hitung $-0,148$ lebih kecil dari t-tabel 2,028, maka pada tingkat kekeliruan $5 \% \mathrm{Ho}_{\mathrm{O}}$ diterima dan $\mathrm{Ha}_{\mathrm{a}}$ diterima (hipotesis ditolak) dan dengan nilai signifikan 0,88 $>0,05$ artinya tidak signifikan. Maka dapat dikatakan bahwa promosi $\left(\mathrm{X}_{2}\right)$ secara parsial tidak siginfikan terhadap minat nasabah (Y).

\section{Pengaruh proses terhadap minat nasabah.}

Hasil analisis memberikan bukti bahwa kausalitas antara proses $\left(\mathrm{X}_{3}\right)$ dengan minat nasabah $(\mathrm{Y})$ diperoleh data yakni thitung 1,248 lebih kecil dari ttabel 2,028, maka pada tingkat kekeliruan $5 \% \mathrm{H}_{\mathrm{O}}$ diterima dan $\mathrm{Ha}$ ditolak dan dengan nilai signifikan $0,22>0,05$ artinya tidak signifikan. Maka dapat dikatakan bahwa proses $\left(\mathrm{X}_{3}\right)$ secara parsial memiliki berpengaruh positif namun tidak signifikan terhadap minat nasabah $(\mathrm{Y})$.

Uji Koefisien Determinan Tabel 17. Uji $\mathbf{R}^{2}$

\begin{tabular}{|c|c|}
\hline $\mathrm{R}$ & R Square \\
\hline 0,655 & 0.429 \\
\hline
\end{tabular}

Tabel 17 menunjukkan hasil R2 yaitu sebesar 0,429 atau $42,9 \%$ besarnya minat nasabah yang dipengaruhi oleh variabel produk, promosi, dan proses. Sedangkan $57,1 \%$ minat nasabah dipengaruhi oleh variabel diluar penelitian yang dilakukan.

\section{Uji Linearitas}

Tabel 18. Uji Linearitas

\begin{tabular}{|c|l|c|}
\hline \multirow{3}{*}{$\begin{array}{c}\text { Minat } * \\
\text { Produk }\end{array}$} & (Combined) & Sig. \\
\cline { 2 - 3 } & \multicolumn{1}{|c|}{ Linearity } & .039 \\
\cline { 2 - 3 } & $\begin{array}{c}\text { Deviation from } \\
\text { Linearity }\end{array}$ & .558 \\
\hline & & Sig. \\
\hline \multirow{3}{*}{$\begin{array}{c}\text { Minat } * \\
\text { Promosi }\end{array}$} & (Combined) & .054 \\
\cline { 2 - 3 } & Linearity & $\begin{array}{l}\text { Deviation from } \\
\text { Linearity }\end{array}$ \\
\hline
\end{tabular}




\begin{tabular}{|c|c|c|} 
& & Sig. \\
\hline \multirow{3}{*}{$\begin{array}{c}\text { Minat } * \\
\text { Proses }\end{array}$} & (Combined) & .057 \\
\cline { 2 - 3 } & Linearity & .000 \\
\cline { 2 - 3 } & $\begin{array}{c}\text { Deviation from } \\
\text { Linearity }\end{array}$ & .511 \\
\hline
\end{tabular}

Hasil pengujian linearitas dari ketiga dimensi pengamatan yaitu produk, promosi dan proses memberikan bukti jika nilai deviation from linearity $>0.05$. Sehingga dapat dinyatakan bahwa terdapat hubungan linear antara dimensi pengamatan penilitian terhadap Minat Nasabah.

\section{PEMBAHASAN}

Pengaruh Produk terhadap minat nasabah

Produk (product), adalah mengelola unsur produk termasuk perencaan dan pengembangan produk atau jasa yang tepat untuk dipasarkan dengan mengubah produk atau jasa yang ada dengan menambah dan mengambil tindakan yang lain yang mempengaruhi bermacam-macam produk atau jasa.

Berdasarkan hasil analisis regresi linear berganda yang telah dilakukan menunjukkan bahwa variabel dimensi produk memiliki pengaruh yang (positif) terhadap minat nasabah, yang berarti bahwa semakin meningkatnya nilai suatu produk maka akan meningkatkan minat nasabah, begitu pula sebaliknya menurunya nilai suatu produk akan menurunkan minat nasabah dalam menggunakan e-banking.

Hasil pengujian hipotesis parsial (Uji t) ditemukan bahwa dimensi produk dalam penelitian ini memiliki pengaruh yang signifikan terhadap minat nasabah dalam menggunakan e-banking. sehingga hipotesis dalam penelitian ini yang menyatakan produk berpengaruh positif dan signifikan terhadap minat nasabah.

Hal ini terjadi karena bauran pemasaran pada dimensi produk dapat mempermudah nasabah dalam bertransaksi, kapan pun dimana saja, dan sangat praktis dalam penggunaanya.. Selain itu beberapa nasabah, masih belum berminat menggunakan produk e-banking, dikarenakan e-banking masih memiliki risiko yang sangat tinggi. Jadi dengan kata lain peningkatan nilai suatu produk akan memberikan dampak bagi nasabah dalam menggunakan e-banking. Hasil penelitian sesuai dengan hasil penelitian sebelumnya yang dilakukan oleh Olga Corry (2019) dimana dimensi produk memiliki pengaruh positif dan signifikan terhadap minat nasabah semakin tinggi kesusaian nasabah dengan produk yang ditawarkan perbankan, maka semakin tinggi minat nasabah menggunakan layanan E-Banking.

Pengaruh Promosi terhadap minat nasabah.

Promosi (promotion), adalah salah satu unsur yang digunakan untuk memberitahukan dan membujuk pasar tentang produk atau jasa yang baru pada perusahaan melalui iklan, penjualan pribadi, promosi penjualan, maupun publikasi. Berdasarkan hasil analisis regresi linear berganda yang telah dilakukan menunjukkan bahwa variabel dimensi promosi tidak memiliki pengaruh terhadap minat nasabah, yang berarti bahwa meningkatnya efektifitas promosi tidak akan meningkatkan minat nasabah.

Berdasarkan hasil pengujian hipotesis parsial (Uji t) ditemukan bahwa variabel dimensi promosi dalam penelitian ini tidak signifikan terhadap minat nasabah dalam menggunakan e-banking, sehingga hipotesis dalam penelitian ini yang menyatakan promosi berpengaruh positif namun tidak signifikan terhadap minat nasabah dinyatakan ditolak.

Hal ini terjadi karena bauran pemasaran pada dimensi promosi tidak begitu direspon dengan baik atau dengan kata lain nasabah tidak terpengaruh dengan promosi dari nasabah dimana perbankan perlu meningkatkan promosi dengan mengadakan berupa iklan, brosur, dan lainnya untuk menunjang informasi agar nasabah mengetahui jasa layanan nasabah sehingga nasabah tidak ragu untuk memilih layanan yang ditawarkan.

Hasil penelitian ini tidak sesuai dengan hasil penelitian sebelumnya yang dilakukan oleh Muasyaroh (2014); Sjahruddin, H., \& Akbar, S. (2020) dimana dimensi promosi memiliki pengaruh positif dan signifikan terhadap minat nasabah semakin baik promosi yang dilakukan bank kepada nasabah, maka semakin tinggi minat nasabah menggunakan layanan E-Banking.

\section{Pengaruh Proses terhadap Minat Nasabah}

Proses merupakan gabungan dari keseluruhan aktivitas. Mulai dari prosedur, jadwal pekerjaan, aktivitas, mekanisme, serta 
hal-hal rutin lainnya. Berdasarkan hasil analisis regresi linear berganda yang telah dilakukan menunjukkan bahwa variabel dimensi proses memiliki pengaruh yang (positif) terhadap minat nasabah, yang berarti bahwa semakin meningkatnya suatu proses maka akan meningkatkan minat nasabah, begitu pula sebaliknya menurunya nilai suatu proses akan menurunkan minat nasabah dalam menggunakan $e$-banking.

Berdasarkan hasil pengujian hipotesis parsial (Uji t) ditemukan bahwa variabel dimensi proses dalam penelitian berpengaruh positif tidak signifikan terhadap minat nasabah dalam menggunakan e-banking, sehingga hipotesis dalam penelitian ini yang menyatakan proses berpengaruh positif namun tidak signifikan terhadap minat nasabah. dinyatakan diterima.

Hal ini terjadi karena penggunaan layanan online tidak dapat dipahami dan dioperasikan oleh pengguna, sehingga dapat disimpulkan semakin mudah nasabah dalam mengoperasikan layanan e-banking maka semakin banyak nasabah yang berminat untuk menggunaknya. Hasil penelitian ini tidak sesuai dengan hasil penelitian sebelumnya yang dilakukan oleh Ritonga (2017); Wirawan, A. A., Sjahruddin, H., \& Razak, N. (2019) dimana dimensi proses terhadap minat nasabah semakin baik proses yang dilakukan bank kepada nasabah, maka semakin tinggi minat nasabah menggunakan layanan $E$ -

Banking.

\section{KESIMPULAN DAN SARAN KESIMPULAN}

Hasil pengujian pengaruh dimensi produk terhadap minat nasabah diperoleh koefisien regresi sebesar 0,370 . Hipotesis yang dibangun pada variabel ini adalah produk berpengaruh positif signifikan terhadap minat nasabah. Sedangkan nilai probabilitas signifikansi sebesar 0,02 lebih kecil dari 0,05, sehingga dapat disimpulkan bahwa variabel produk berpengaruh positif dan signifikan terhadap minat menggunakan E-Banking PT. Bank BNI Syari'ah Kantor Cabang Makassar. Hal ini terjadi karena bauran pemasaran pada dimensi produk dapat mempermudah nasabah dalam bertransaksi, kapan pun dimana saja, dan sangat praktis dalam penggunaanya.

Hasil pengujian pengaruh dimensi promosi terhadap minat nasabah diperoleh koefisien regresi sebesar -0,035. Hipotesis yang dibangun pada variabel ini adalah promosi berpengaruh positif signifikan terhadap minat nasabah. Sedangkan nilai probabilitas signifikansi sebesar 0,88 lebih besar dari 0,05 , sehingga dapat disimpulkan bahwa variabel promosi tidak berpengaruh terhadap minat menggunakan E-Banking.

Hal ini terjadi karena bauran pemasaran pada dimensi promosi tidak begitu direspon dengan baik atau dengan kata lain nasabah tidak terpengaruh dengan promosi dari nasabah dimana perusahaan perlu meningkatkan promosi dengan mengadakan berupa iklan, brosur, dan lainnya untuk menunjang informasi agar nasabah mengetahui jasa layanan nasabah sehingga nasabah tidak ragu untuk memilih layanan yang ditawarkan.

Hasil pengujian pengaruh variabel proses terhadap minat nasabah diperoleh koefisien regresi sebesar 0,277. Hipotesis yang dibangun pada variabel ini adalah proses berpengaruh positif signifikan terhadap minat nasabah. Sedangkan nilai probabilitas signifikansi sebesar 0,22 lebih kecil dari 0,05. Hal ini terjadi karena penggunaan layanan online tidak mudah dipahami dan dioperasikan oleh pengguna, sehingga dapat disimpulkan semakin mudah nasabah dalam mengoperasikan layanan e-banking maka semakin banyak nasabah yang berminat untuk menggunakanya.

Hasil pengujian variabel yang paling dominan terhadap minat nasabah dalam menggunakan e-Banking yaitu variabel bauran pemasaran pada dimensi produk dengan nilai probabilitas signifikansi sebesar 0,002 lebih kecil dari 0,05, dan t-hitung 2,276 lebih besar dari t-tabel 2,028 maka dapat disimpulkan bahwa variabel bauran pemasaran dimensi proses yang paling doiminan dalam meningkatkan minat nasabah dalam menggunakan e-banking.

\section{SARAN}

Kepada peneliti selanjutnya agar dapat menambah atau mengganti variabel- variabel independen lainnya seperti variabel kepercayaan, keamanan dan variabel lain yang dapat meningkatkan minat nasabah menggunakan e- banking.

Kepada perbankan syariah diharapkan untuk lebih meningkatkan pelayanan bagi nasabah. Nasabah merupakan salah satu bagian 
dari atau asset berlangsungnya proses usaha. Oleh karena itu, PT. Bank BNI Syari'ah harus lebih memperhatikan dan memelihara nasabah dengan mempertahankan kepercayaan nasabah yang diberikan pada bank. E-banking merupakan layanan 24 jam yang akan sangat membantu nasabah dalam kegiatan perbankan semoga bisa disosialisasikan lebih luas lagi pada nasabah.

\section{REFERENSI}

Alwi, P. N. (2019). Pengaruh bauran pemasaran terhadap minat nasabah menggunakan layanan e-banking PT. Bank Rakyat Indonesia (Persero) unit cawas cabang Klaten (Doctoral dissertation, Universitas Widya Dharma).

Ayuningtyas, O. C. (2019). Pengaruh Bauran Pemasaran Terhadap Minat Nasabah Menggunakan E-Banking (Studi pada BSM KCP Teluk Betung Bandar Lampung) (Doctoral dissertation, UIN Raden Intan Lampung).

Hurriyati, R. (2015). Bauran pemasaran \& loyalitas konsumen. Bandung: Alfabeta.

Jaringan Tim OJK (2015). Survei Nasabah Bank di Indoesia,

Kasmir, D., \& SE, M. (2012). Manajemen Perbankan Edisi Revisi. Jakarta: Penerbit PT Raja Grafindo Persada.

Muasyaroh, H. H. (2014). Pengaruh Bauran Pemasaran terhadap Minat Nasabah Menggunakan E-Banking PT. Bank BNI Syariah Yogyakarta. SkripsiUniversitas Islam Sunan Kalijaga.

Ningsih, E. R. (2017). Studi Eksplorasi Penerapan Etika Bisnis Pada Perbankan Syari'ah Di Indonesia. Iqtishadia: Jurnal Kajian Ekonomi dan Bisnis Islam STAIN Kudus, 10(1), 1-22.

Oliver;1986 dalam Ramli dan Sjahruddin, (2015) Theory Disconfirmation

Pinontoan, W. (2013). Pengaruh e-banking, kualitas pelayanan, kualitas komunikasi dan kepercayaan terhadap loyalitas nasabah pada pt. Bank mandiri cabang manado. Jurnal EMBA: Jurnal Riset Ekonomi, Manajemen, Bisnis dan Akuntansi, 1(4).
Ramli, A. H., \& Sjahruddin, H. (2015). Building patient loyalty in healthcare services. International Review of Management and Business Research, 4(2), 391.

Ritonga, H. S. P. (2017). Pengaruh bauran pemasaran terhadap minat nasabah menggunakan e-banking pada PT. Bank Syariah Mandiri kantor cabang Padangsidimpuan (Doctoral dissertation, IAIN Padangsidimpuan).

Schiffman, L. G., \& Kanuk, L. L. (2010). Consumer behavior. Harlow, England: Prentice Hall.

Setyaningsih, E. D. (2017). Pengaruh Kualitas Layanan Dan Word Of Mouth Melalui Minat Terhadap Keputusan Nasabah Dalam Menggunakan E-Banking Pada Bank Bni. Jurnal Ilmiah Ekonomi Bisnis, 22(1).

Sjahruddin, H., \& Akbar, S. (2020). Dampak Promosi, Harga, Dan Diferensiasi Produk Dalam Meningkatkan Keputusan Pembelian. Jurnal Administrasi dan Manajemen, 10(2), 172-179.

Sumirat, M. Y. (2015). Pengaruh Pemasaran Interaktif terhadap Keputusan Pembelian (Studi Kasus Distro Dloops Bandung) (Doctoral dissertation, Fakultas Ekonomi Dan Bisnis (UNISBA)).

Supriyanto, A. S. (2010). Metodologi riset manajemen Sumber daya Manusia.

Tjiptono, F. (2012). Pemasaran jasa. Malang: Bayumedia Publishing, 104.

Wirawan, A. A., Sjahruddin, H., \& Razak, N. (2019). Pengaruh Kualitas Produk dan Lokasi Terhadap Loyalitas Pelanggan Melalui Kepuasan Pelanggan Sebagai Variabel Intervening Pada Lamuna Coffee di Kabupaten Bone.

Wulandari, D. P. (2018). Faktor-faktor yang mempengaruhi minat nasabah untuk menggunakan layanan mobile banking pada PT Bank Syariah Mandiri kantor cabang Lubuk Pakam (Doctoral dissertation, Universitas Islam Negeri Sumatea Utara Medan). 